\title{
炭素化過程における強磁場印加によるPAN系崖素織維の強化
}

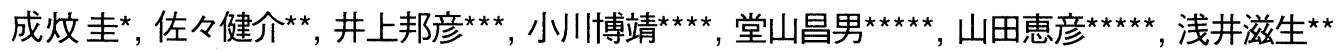

\section{Strengthening of PAN-Based Carbon Fibers by Imposing a High Magnetic Field in a Carbonization Process}

\author{
Mun-Gyu Sung*, Kensuke Sassa**, Kunihiko Inoue***, Hiroyasu Ogawa****, Masao Doyama*****, \\ Shigehiko Yamada***** and Shigeo Asai**
}

\begin{abstract}
Carbon fibers produced from PAN (polyacrylonitrile) as a precursor are generally subjected to the three heat treatment processes of stabilization and carbonization followed by graphitization. The fibers that had been stabilized in the first process were carbonized in a high magnetic field imposed parallel to fiber axis at the temperature of $1445 \mathrm{~K}$ and graphitized without magnetic field at $2273 \mathrm{~K}$. The tensile strength of these treated fibers was increased in $15 \sim 31 \%$ in comparison with that of the fibers treated in no magnetic field. The reason why the imposition of the magnetic field could improve the strength of fibers has been studied through the methods such as a microscopic observation of fiber surfaces, a statistical Weibull analysis, an X-ray diffraction and a Raman spectroscopy. By using of the observed and measured results, the mechanism of strengthening of PAN-based carbon fibers by imposing the high magnetic field has been discussed on the basis of an intermolecular cross-linking reaction in terms of a radical pair theory in a magnetic field.
\end{abstract}

KEYWORDS : PAN-based carbon fibers, Carbonization, High magnetic field, Nonmagnetic material, Electromagnetic processing of materials

\section{1. 緒 言}

炭素緎維は他の材料と比べて軽量で高い強度と弾性率を有 し,かつ酎熱性に優れた高性能な構造材料であり, 複合材料の 強化材として主に使用されている”。特に, 航空・宇宙分野で 多用される飛翔体および列車, 自動車, 船舶等の輪送体の高速 化を実現する上で必須の材料といわれ，今後, 基幹産業を支え る最重要材料の1つと位置づけられている。

PAN (Polyacrylonitrile) 系炭素繊維はポリアクリロニトリ ルを前駆体とするもので, 延伸操作を加えながら熱処理を行 うことにより, 引張強度や弾性率を増加させることができる が, 現在その引張強度の到達值は理論值の数\%, 引張弾性率は 約 $80 \%$ の域にとどまっている。この機械的特性值が理論值と
大きく異なる理由にはグラファイト層面の低次元構造状態の 不完全性が挙げられている2)。

近年, 超電導磁石の普及に伴い強磁場が比較的容易に入手 可能となり, 炭素のような非磁性物質に対しても磁場の影響 が見られることがわかり $\left.{ }^{3)}, 4\right)$, 新しい材料製造プロセスの展開 が期待されている。そして, 材料プロセッシングにおける強 磁場印加の効果に関する研究としては, 化学反応の制御, 材料 の諸機能の向上を図る試みがされている5),6)。しかし,これら の研究は液相状態での化学反応を取り扱ったもので, 固相状 態での化学反応に及ぼす磁場の効果を取り扱った研究はほと んどなされていない。森田ら7),8 リマーの化学反応を磁場中で行うと, ラジカル対機構によっ てポリマーの溶解性や表面の化学反応性が変わることを見い

* 名古屋大学大学院生：干464-8603 名古屋市千種区不老町

* Graduate Student, Graduate School of Engineering, Nagoya University : Furo-cho, Chikusa-ku,Nagoya 464-8603, Japan

** 名古屋大学工学研究科： $\overline{1} 464-8603$ 名古屋市千種区不老町

** Department of Materials Processing Engineering, Nagoya University : Furo-cho, Chikusa-ku, Nagoya 464-8603, Japan

*** 東邦テナックス株式会社：テ113-0033 東京都文京区本郷2丁目38-16

*** Corporate and Planning Division, Toho Tenax Co., Ltd : 38-16, Hongo-nichome, Bunkyo-ku, Tokyo, 113-0033, Japan

**** 元東邦テナックス株式会社：干113-0033 東京都文京区本郷2丁目38-16

**** Former working place : Corporate and Planning Division, Toho Tenax Co., Ltd. : 38-16, Hongo-nichome, Bunkyo-ku, Tokyo, 113-0033, Japan

*****帝京科学大学理工学部：テ409-0193 山梨県北都留郡上野原町八ツ沢2525

***** Department of Science and Engineering, Teikyo University of Science \& Technology : 2525 Yatsusawa, Uenohara-cho, Kitatsuru-gun, Yamanashi 409-0193, Japan 
だしている。著者ら゙はPAN系炭素瀻維の製造過程中の1つ である炭素化過程に強磁場を印加することによって, 無磁場 下では表面欠陥が発生する条件の下でも欠陥の発生を抑制で きることを報告した。また, 伊藤ら ${ }^{10}$ はPAN系炭素瀻維の製 造過程中の黑鉛化過程に磁場を印加することによって瀻維強 度が増加することを明らかにした。

本研究では炭素繊維の炭素化過程に強磁場を印加すること により,繊維の強度と弾性率の向上を図った。また, X線回折, ラマン分光, SEM観察によって繊維の結晶構造や組織に関す るパラメー夕を求め, 橋かけ反応に関するラジカル対機構に 基づいて強磁場印加による炭素繊維の強化機構を検討する。

\section{2. 実験方法}

実験装置図をFig.1に示す。反応管内の雾囲気を $99.9999 \%$ のArにした後, 瀻維を挿入し, 上部開口部にArを流して大気の 侵入を防いだ。次に $14 \mathrm{~g}$ の黑鉛板を荷重として供試材である PANの安定化处理繊維に張力を加えつつ, $0,0.5,1,3,5,8,12 \mathrm{~T}$

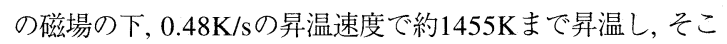
で600秒間保持した後, 炉冷した。次に, 得られた炭素化瀻維 を約2273Kで1200秒間, 無磁場下で黒鉛化処理を行った。な お, 温度は赤外放射温度計を用いて測定した。

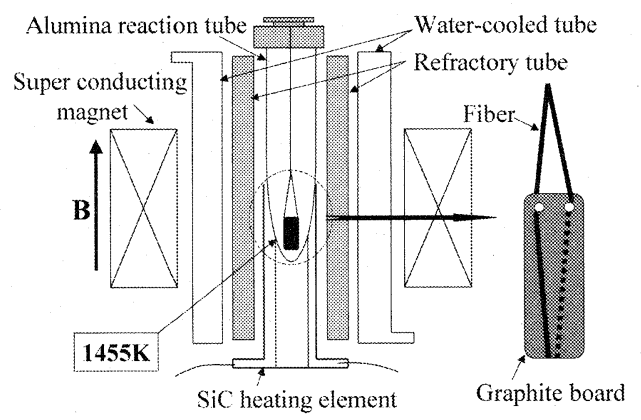

Fig.1 Schematic view of experimental apparatus and sample setting configuration in carbonization process.

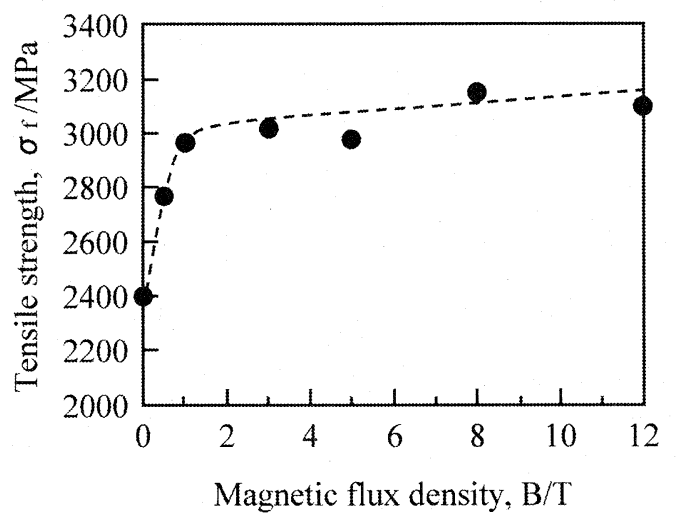

Fig.2 Relationship between tensile strength and magnetic flux density.
このようにして得られた纎維は走査型電子顕微鏡 (SEM) によって表面観察, $\mathrm{X}$ 線回折による結晶子サイズ $\mathrm{L}_{c}$, 結晶子面 間隔 $\mathrm{d}_{002}$ およひひ配向度の測定, ラマン分光による分子構造の測 定および引張試験機による引張強度の測定に供した。

\section{3. 実験結果}

印加磁場強度と得られた絨維の引張強度との関係を Fig.2 に示す。磁場強度の増加とともに平均引張強度は1Tまでは顥 著な増加を示し, 1Tを超えると増加の程度は鈍化している。 磁場印加による纎維強度の増加率は15.8～31.8\%（378～ $761 \mathrm{MPa})$ で, 炭素化過程に执いても黒鉛化過程と同様(1), 磁場 印加によって引張強度が向上した。

Fig.3にSEMで観察した瀻維の表面写真を示す。磁場あり， 磁場なしに関係なく欠陥のない清浄な表面が得られており 前報9)とは異なる結果となった。Fig.4は得られた引張強度の 2母数Weibull分布を示す。印加磁場の変化にもかかわらず Weibull分布は直線を示すことから, 破壊モードおよび破壞原 因も磁場印加の有無によって変らなかったと推察した。前報り と異なる結果となった理由は本実験で採用した保持時間が前 報9)の実験のそれと比較して短かったためと判断した。通常, 炭素繊維には内部欠陥と表面欠陥があり"1)，特に表面欠陥が

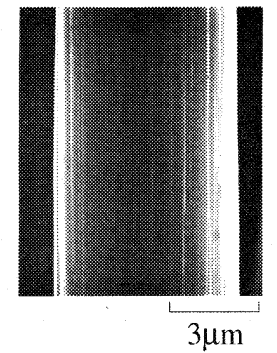

OT

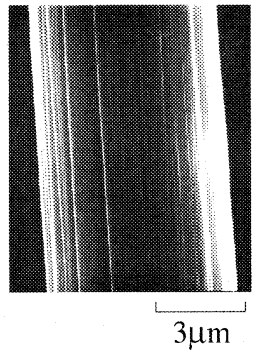

$12 \mathrm{~T}$
Fig.3 SEM micrographs for the surface of a carbon fiber.

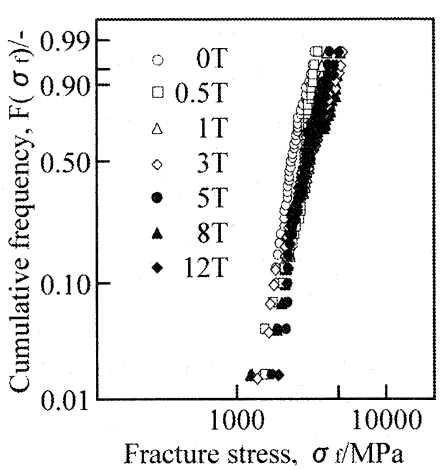

Fig.4 Two-parameter Weibull plots on tensile strength. 


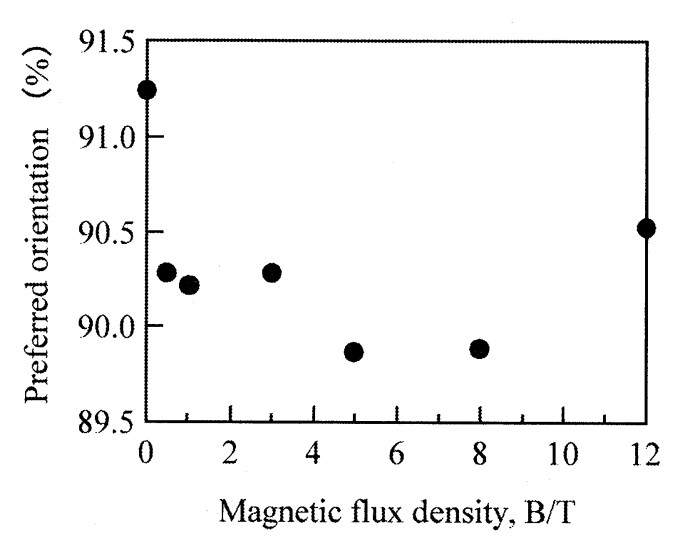

Fig.5 Relationship between preferred orientation and magnetic flux density.

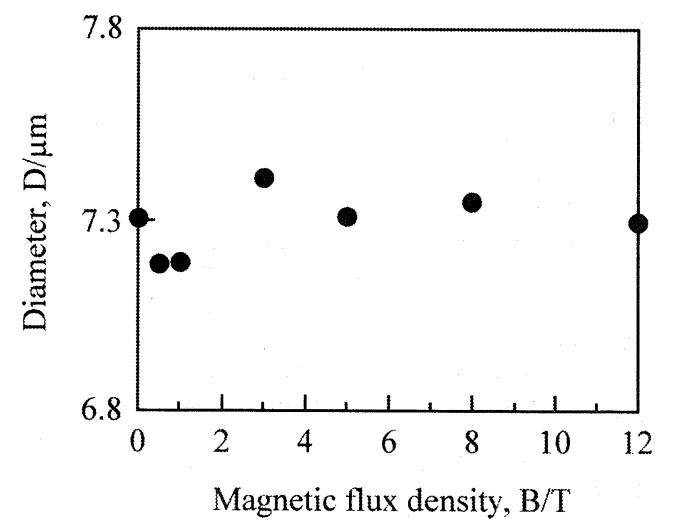

Fig.6 Relationship between diameter and magnetic flux density.

あると繊維強度は大きく低下するが, Fig.3 と Fig.4の結果から, 破壊原因は内部欠陥のみであると推測できる。Fig.5に印加 磁場と結晶配向度との関係を示す。一般に繊維の強度は炭素 の共有結合に起因し, 結晶の配向度が高くなるとともに共有 結合の割合が増加して繊維の強度が増加する。しかし, 本実 験での結晶配向度は磁場の印加により $1 \sim 1.5 \%$ 程減少してい るにもかかわらず䋊維強度が増加したことから, 繊維強度の 増加は結晶の配向度のみによるのではなく他の要因も関係す ると考えられる。通常, 直径が減少すると, 寸法効果により引 張強度が増加すると言われている12) が, 本実験では, 䋊維直径 と印加磁場との関係はFig.6に示すように若干のばらつきが あるもののほぼ一定の值を示している。つまり, 本実験での 引張強度の増加は繊維径とは直接関係しないことがわかる。 以上の結果から, 磁場印加による引張強度の増加の理由は表 面欠陥, 結晶配向, 繊維直径には依らないと判断した。

次に, Fig.7には印加磁場の強度をパラメータとして, 炭素 繊維表面のラマンスペクトルの測定例を示す。1355 $\mathrm{cm}^{-1}$ と $1580 \mathrm{~cm}^{-1}$ のラマンピークの強度比 $\mathrm{R}\left(=\mathrm{I}_{1355} / \mathrm{I}_{1580}, \mathrm{I}_{\mathrm{D}} / \mathrm{I}_{\mathrm{G}}\right)$ 值と印 加磁場強度の関係をFig.8に示す。R值は印加磁場の増加とと

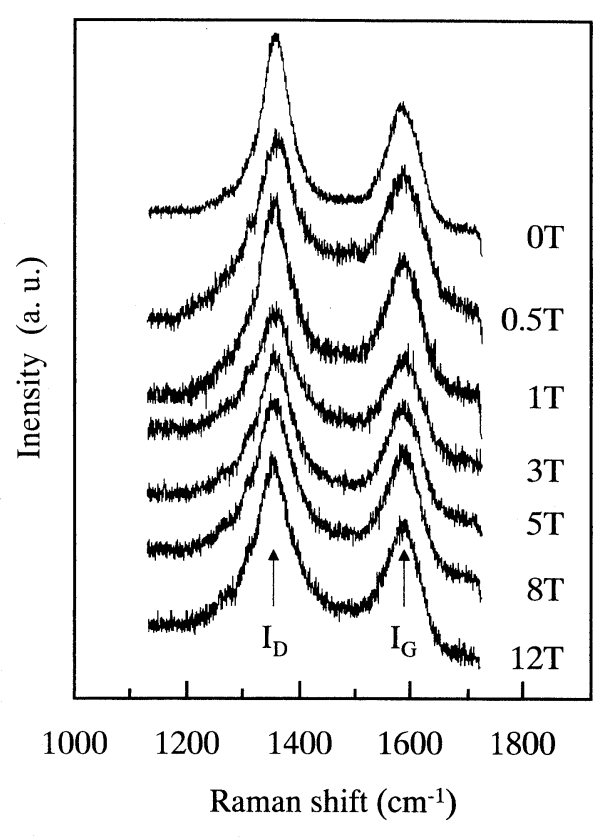

Fig.7 Raman spectra of carbon fibers at various applying magnetic field.

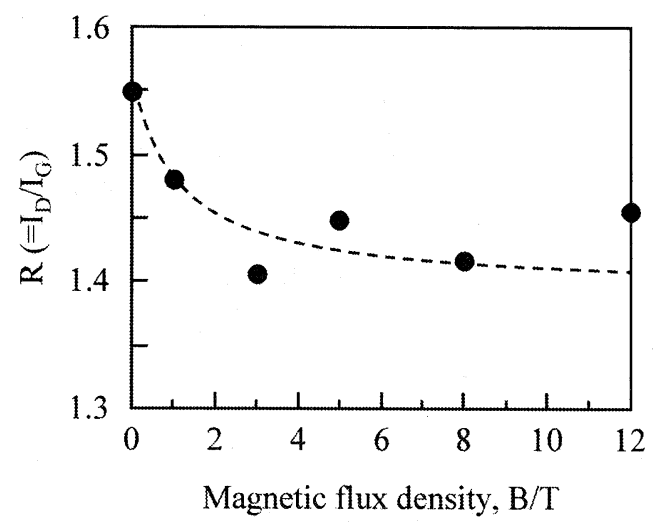

Fig.8 $R\left(=I_{D} / I_{G}\right)$ intensity ratio of Raman spectra as a function of magnetic flux density.

もに減少する傾向を示している。一方, R值は結晶子サイズ $\mathrm{L}_{a}$ と密接な関係があり ${ }^{13)-15)}$, 実験式である (1) 式を用いてR值か ら $\mathbf{L}_{a}$ を求めることができる(16)-18)。

$$
\mathrm{L}_{a}=43.5 / \mathrm{R}[\AA]
$$

R值から得られた $\mathrm{L}_{a}$ と印加磁場との関係をFig.9 (a) に示す。 結晶子サイズ $\mathrm{L}_{a}$ はわずか $0.5 \mathrm{~T}$ の印加磁場によって大きく増加 し, その増加量は12Tを印加したものとほとんど変わりなく, その増加量は $0.15 \sim 0.3 \mathrm{~nm}$ である。結晶子サイズ $\mathrm{L}_{c}$ と面間隔 $\mathrm{d}_{002}$ に対する印加磁場との関係をFig.9の (b) と (c) にそれぞ れ示す。結晶子サイズ $\mathrm{L}_{c}$ は1Tの磁場印加で急激に減少し, $1 \mathrm{~T}$ 
(a)

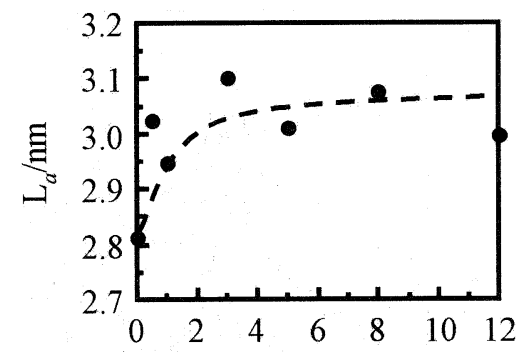

Magnetic flux density, B/T

(b)

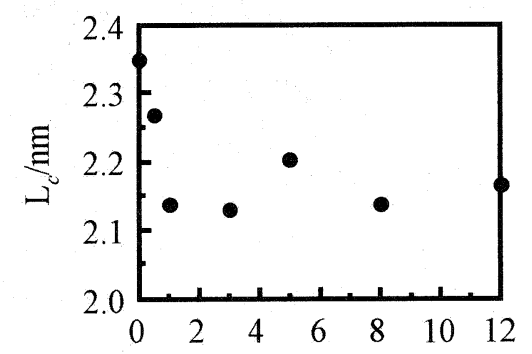

Magnetic flux density, B/T

(c)

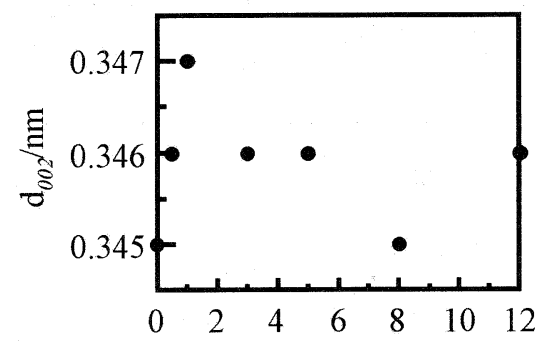

Magnetic flux density, B/T

Fig.9 Effect of imposition of magnetic field on microcrystalline structure parameters of carbon fibers.

Table 1 Experiment Results.

\begin{tabular}{|c|c|c|c|c|c|c|}
\hline \multirow{2}{*}{$\begin{array}{l}\text { Magnetic } \\
\text { field } \\
(\mathrm{T})\end{array}$} & \multicolumn{2}{|c|}{$\begin{array}{c}\text { Raman } \\
\text { spectroscopy }\end{array}$} & \multicolumn{3}{|c|}{$\mathrm{X}$-ray diffraction } & \multirow{2}{*}{\begin{tabular}{|c|}
$\begin{array}{c}\text { Tensile } \\
\text { property }\end{array}$ \\
$\begin{array}{c}\text { Tensile } \\
\text { strength } \\
(\mathrm{MPa})\end{array}$
\end{tabular}} \\
\hline & $\begin{aligned} & R \\
(= & \left.I_{D} / I_{G}\right)\end{aligned}$ & $\begin{array}{c}\mathrm{L}_{a} \\
(\mathrm{~nm})\end{array}$ & $\begin{array}{c}\mathrm{d}_{002} \\
(\mathrm{~nm})\end{array}$ & $\begin{array}{c}\mathrm{L}_{c} \\
(\mathrm{~nm})\end{array}$ & $\begin{array}{c}\text { Preferred } \\
\text { orientation } \\
(\%)\end{array}$ & \\
\hline 0 & 1.548 & 2.811 & 0.345 & 2.346 & 91.24 & 2394 \\
\hline 0.5 & 1.440 & 3.021 & 0.346 & 2.268 & 90.28 & 2772 \\
\hline 1 & 1.478 & 2.944 & 0.347 & 2.138 & 90.22 & 2966 \\
\hline 3 & 1.404 & 3.098 & 0.346 & 2.130 & 90.28 & 3022 \\
\hline 5 & 1.446 & 3.008 & 0.346 & 2.203 & 89.87 & 2976 \\
\hline 8 & 1.415 & 3.075 & 0.345 & 2.139 & 89.89 & 3155 \\
\hline 12 & 1.453 & 2.993 & 0.346 & 2.166 & 90.53 & 3092 \\
\hline
\end{tabular}

を超えるとほぼ一定な值を示し, 面間隔は8Tでのデータを除 けば, 磁場ありが磁場なしより高い值を示している。得られ た実験結果をTable 1にまとめて示した。Fig.9に示した磁場 印加による結晶構造パラメータの変化を黒鉛化の観点から見

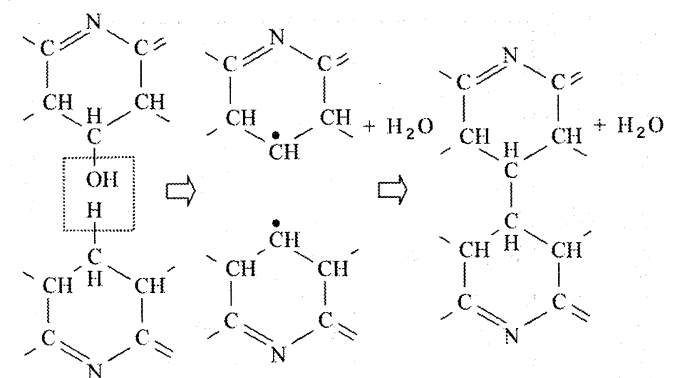

(a)

(b)

(c)

Fig.10 Schematic view on intermolecular cross-linking mechanism in carbonization process of stabilized fibers.

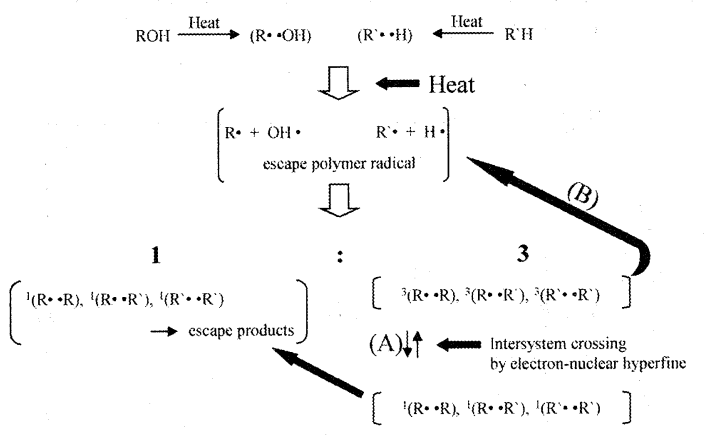

Fig.11 Intermolecular cross-linking mechanism in carbonization process of stabilized fibers without magnetic field.

ると, 面間隔 $\mathrm{d}_{002}$ の増加や結晶子サイズ $\mathrm{L}_{c}$ の減少は黒鉛化度の 低下を示し, 結晶子サイズ $\mathrm{L}_{a}$ の増加は黒鉛化度の増大を示す ものと言える。

\section{4. 考察}

炭素化過程には2つの化学反応の段階がある19)。第1段階は $600^{\circ} \mathrm{C}$ までの低温域で生じるもので, 大部分の化学反応や揮発 物の蒸発がここで起こる。例えば, 梯子型ポリマー鎖の脱水 による橋かけ反応はこの段階で活発化するため, 昇温速度を $5^{\circ} \mathrm{C} / \mathrm{min}$ 以下として繊維をゆっくり熱处理することが望まれ ている。第2段階は $600^{\circ} \mathrm{C}$ と $1500^{\circ} \mathrm{C}$ の間で, 発熱や蒸発等に起 因する構造損の可能性は減少するため, 1段階より早い速度で 熱処理ができる。この段階ではN $\mathrm{N}_{2}$ と HCNはポリマー鎖の橋 かけ反応によって, $\mathrm{H}_{2}$ は脱水素反応によって蒸発する。

Fig.10に炭素化過程における脱水反応の理想的な橋かけ反 応機構を概念図として示す。Fig.10 (a) は酸化処理された緎 維の代表的な構造を示している。熱処理によってFig.10 (b) のようにFig.10 (a) のROHとR'Hからホモリシス (homolysis) して生成したラジカルRとR'が散逸してフリーラジカルにな り,これらの衝突によってポリマー鎖間の橋かけ反応が進行 する $(\mathbf{F i g . 1 0}(\mathrm{c}))$ 。このフリーな散冕ラジカルの衝突の際生 成する1重項ラジカル対と3重項ラジカル対の割合は1：3であ る6),20)。無磁場下ではFig.11に示すように3重項ラジカル対が 


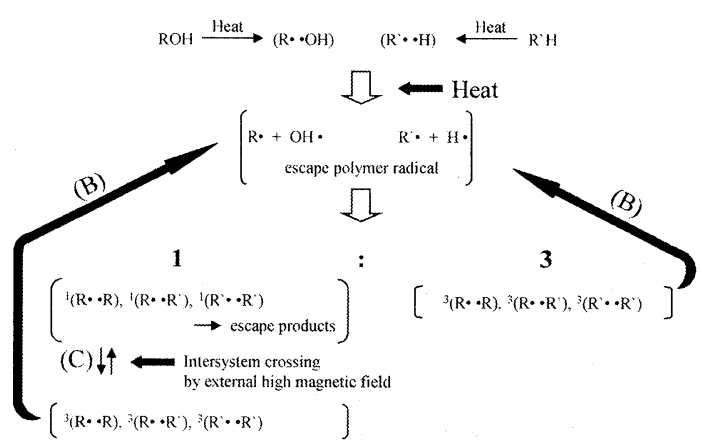

Fig.12 Intermolecular cross-linking mechanism in carbonization process of stabilized fibers under the imposition of high magnetic field.

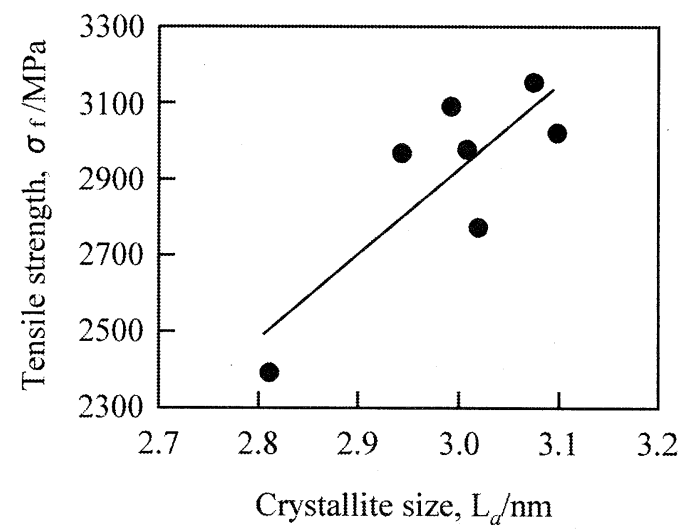

Fig.13 Relationship between crystallite size $\mathrm{L}_{a}$ and tensile strength.

散逸ラジカルとなって $(\mathrm{B})$ ループを形成することより核スピ ンと電子スピンの相互作用によって 3 重項ラジカル対から 1 重 項ラジカル対への項間交差 (A) が優先的に起こるため, 反応 性が高い1重項ラジカル対の割合が増加して橋かけ反応が促 進されることになる。その結果, グラファイト層面構造に構 造損が生じる可能性が高くなると考えられる。一方, 強磁場 が印加されていると核スピンと電子スピンの相互作用が無視 できるため, Fig.12に見るとおり,Fig.11に(A) として示した3 重項ラジカル対から1重項ラジカル対への項間交差がなくな る。さらに, 強磁場印加によって1重項ラジカル対から 3 重項 ラジカル対への項間交差 (C) が生じ, 3 重項ラジカル対の割合 が磁場なしの場合と比べて増加する。その上, 各3重項ラジカ ル対はスピン状態の違いから3重項ラジカル対間の再結合は 起こりにくいため, 3 重項ラジカル対は散逸してフリーラジカ ルとなり, (B) ループを形成するので, 散逸ラジカルの割合が 磁場なしの場合と比較して増加する。つまり, 磁場印加によ って磁場なしの場合より反応物である1重項ラジカル対の割 合が減少し, 反応物生成速度が遅くなり,より規則的なグラフ アイト層面構造となると仮定した。この考えに基づけば, Fig.9 (a) に示した結晶子サイズ $\mathrm{L}_{a}$ の増加は橋かけ反応が磁場
によってより規則的なグラファイト層面構造となった結果と 見ることができる。井本ら ${ }^{21)}$ はメタクリル酸メチル (MMA) のラジカル重合の収率が磁場印加によって増加すると報告し ているが,この結果は本仮定と本実験結果の妥当性を裏付け るものである。

繊維軸方向に配向した炭素繊維の結晶構造の中で,引張強 度に一番大きく影響を及ぼす結晶子パラメー夕は結晶子サイ ズL $\mathrm{L}_{a}$ である。Fig.13に引張強度と結晶子サイズ $\mathrm{L}_{a}$ との関係を 示す。本実験条件のもとでは引張強度は結晶子サイズ $\mathrm{L}_{a}$ の増 加とともに上昇する傾向が見られる。この結果から磁場印加 によってL $\mathrm{L}_{a}$ の増加がなされ, 引張強度の増加につながったと 考えられる。

この考察に基づくと, PAN系炭素繊維製造過程の磁場印加

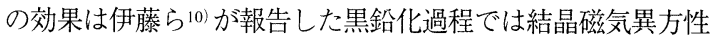
に基づく結晶配向が, またラジカルが多く発生する炭素化過 程ではラジカル反応が効くものと考えられる。

\section{5. 結 論}

PAN系炭素繊維の引張強度を向上させることを目的とし て, PAN系炭素繊維の炭素化過程において磁場を印加し, 炭素 繊維の引張強度に及ぼす磁場印加の影響を統計的分布, 繊維 表面観察, ラマン分光, X線回折を使って調べた。その結果, 以 下の知見を得た。

(1) 炭素繊維製造過程の1つである炭素化過程で磁場を印加 したところ, 炭素繊維の引張強度は15.8～31.8\% (378〜 $761 \mathrm{MPa}$ ) 向上した。印加磁場の増加とともに平均引張 強度は1Tまで顕著な増加を示し, 1Tを超えるとその増 加の程度は鈍化した。

(2) 結晶子サイズ $\mathrm{L}_{a}$ の増加が引張強度の増大につながるこ とを見出した。

(3) 磁場印加によって結晶子州イズ $\mathrm{L}_{a}$ が増加する機構を強磁 場下でのラジカル対機構に基づて定性的に説明した。

\section{謝 辞}

適切な助言と指導を頂きました, 名古屋大学工学研究科の 平野真一教授, 広島大学理学研究科の谷本能文教授に心より 感謝します。また, 本研究の一部は文部科学省科学研究費補 助金「特定領域研究 (B)」によるものであることをここに記し, 深謝いたします。

\section{文 献}

1) J. B. Donnet, T. K. Wang, S. Rebouillat and J. C. M. Peng, Carbon Fibers (1998) pp.499-524, Marcel Dekker, New York.

2) D. J. Johnson, J. Phys. D: Appl. Phys. 20 (1987) 286-291.

3) H. Morikawa, K. Sassa and S. Asai, Mater. Trans. JIM 39 (1998) 814-818

4) N. I. Wakayama and M. Sugie, Physica B 216 (1996) 403-405.

5) P. Atkins, Chem. Brit. 12 (1976) 214-218. 
6) U. E. Steiner and T. Ulrich, Chem. Rev. 89 (1989) 51-147.

7) H. Morita, N. Uchino, Y. Nakamura and T. Yamaoka, J. Appl. Polymer Sci. 38 (1989) 1997-2007.

8) H. Morita and N. Uchino, J. Appl. Polymer Sci. 41 (1990) 2147-2153.

9) M. G. Sung, K. Sassa, T. Tagawa, T. Miyata, H. Ogawa, M. Doyama, S. Yamada and S. Asai, Application of a high magnetic field in carbonization process to increase the strength of carbon fibers, submitted to Carbon.

10) M. Ito, K. Sassa, H. Ogawa, M. Doyama, S. Yamada and S. Asai, TANSO 2000 [No.191] 37-41 [in Japanese].

11) J. W. Johnson and D. J. Thorne, Carbon 7 (1969) 659-661.

12) T. Tagawa and T. Miyata, Mater. Sci. Eng. A238 (1997) 336342.

13) F. Tuinstra and J. L. Koenig, J. Chem. Phys. 53 (1970) 1126-1130.
14) R. J. Nemanich and S. A. Solin, Phys. Rev. B 20 (1979) 392-401.

15) T. C. Chieu, M. S. Dresselhaus and M. Endo. Phys. Rev. B 26 (1982) 5867-5877.

16) T. Gruber, T. W. Zerda and M. Gerspacher, Carbon 32 (1994) 1377-1382.

17) D. S. Knight and W. B. White. J. Mater. Res. 4 (1989) 385393.

18) M. Endo, K. Hakamada, C. Kim, N. Miyazawa and T. Kasai, TANSO 1998 [No.183] 156-161 [in Japanese].

19) J. B. Donnet, T. K. Wang, S. Rebouillat and J. C. M. Peng, Carbon Fibers (1998) p.26, Marcel Dekker, New York.

20) N. J. Turro and B. Kraeutler, Acc. Chem. Res. 13 (1980) 369377.

21) M. Imoto and K. Nomoto, Makromol. Chem. Rapid Commun. 2 (1981) 703-705.

\section{【書評】}

\section{解説・カーボンファミリー \\ 一それぞれの多様性とその評価一}

稲垣道夫 編著（アグネ承風社 刊）

A5版 204頁 本体 4,000円

昨年度 (平成12年) の「カーボン用語辞典」の出版に 引き続いて,このたび, アグネ承風社より「解説・カー ボンファミリー」稲垣道夫編著が発刊された。

位置づけを一言でいうならば, この本は, 炭素材料に 関する基礎的な用語と基本的な評価方法の解説書とも 言うべき内容である。炭素材料に特有の基本的用語に ついて, その言葉の由来から定義について解説し,また, 新しい構造モデルも提案されている。評価方法として は, X線回折, 磁気抵抗効果および細孔構造が取り上げ られ, それらの長所および問題点が指摘されている。 炭素の研究者にとっては,「カーボン用語辞典」と同様 に手元に常備しておきたい本である。

本書の構成は八章からなっている。第一章では, カ 一ボンファミリーの視点から炭素材料それぞれの多様 性と将来性を, 第二章では, ハードカーボン・ソフトカ 一ボンについて, それらの構造と難黒鉛化や易黑鉛化
の機構について, 第三章では, 炭素材料のX線回折につ いて解析方法と注意点について, 第四章ではグラファ イトとグラフェンの用語の相違と使い方について, 第 五章では, 䋊維状炭素材料についてカーボンナノチュ 一ブから炭素繊維までの解説, 第六章では, 炭素材料の 磁気抵抗効果による黑鉛構造の発達とその選択的配向 評価について, 第七章では, 炭素材料にホウ素・窒素等 の異種元素を導入することによる機能発現, 第八章で は, 炭素材料の細孔構造をミクロ孔からマク口孔まで の評価についての構成である。

筆者の長年にわたる炭素材料に関する見解が打ち出 されている。特に種々の炭素材料とそれらの構造をカ 一ボンファミリーという視点でとらえており, 共著者 はいずれもわが国の第一線で活躍されている方々であ る。定価も4000円と購入しやすい。

(小林和夫) 